\title{
When climatologists meet social scientists: ethnographic speculations around interdisciplinary equivocations
}

\section{Renzo Romano Taddei* (1) \\ Sophie Haines** (1)}

\begin{abstract}
This article argues for the need to address the fact that a large amount of conflict over environmental knowledge occurs inside the academy, against the commonsensical perception that it is a mark of the relationship between science and non-science. It proposes a conceptual speculative exercise that uses a framework presented by indigenous ethnology, specifically the theory of Amerindian perspectivism, to address tensions among scientific disciplines in interdisciplinary work. Ethnographic vignettes about contentious encounters between climatologists/meteorologists and social scientists are used as methodological and analytical resources. The paper argues for a non-platonic approach to interdisciplinarity, suggesting that a more productive and realistic attitude treats the collaboration of different disciplines as a case of alliance among "enemies", with the caveat that the concept of enemy should be understood here in terms of the relational philosophies of Amerindian peoples, where antagonistic difference is valued for its constitutive and productive effects on reality.
\end{abstract}

Keywords: Climate change, Interdisciplinarity, Perspectivism, Sociology of science, Conflict.

\footnotetext{
* Federal University of São Paulo (UNIFESP), Santos, SP, Brazil

** University of Edinburgh, Edinburgh, United Kingdom
} 


\section{Introduction}

[ or most academics, the idea of negotiating environmental knowledges ${ }^{1}$ would immediately bring to mind the frontier between science and non-science, or situations where scientists meet non-scientists. The work we will present in this article calls attention to the fact that a great amount of such negotiations - including situations where negotiations fail takes place inside the realm of science. So instead of using science to make sense of non-science, what we will do is attend to troubles inside of science - the challenges of interdisciplinarity, so to speak - and analyze them using, speculatively, a set of concepts developed in philosophy of science and Amazonian indigenous philosophies - specifically, what Eduardo Viveiros de Castro (2002) and Tania Stolze Lima (1996) have called Amerindian perspectivism.

Most academic work on interdisciplinarity has one of two goals. One is to generate "utility and productivity", meaning constructing strategies for diagnosing and disarming everything that makes interdisciplinary work something dysfunctional (see for instance Szostak, 2013; Wallace; Clark, 2014). The other is to produce an explanation grounded in sociology (e.g. Holmwood, 2010), anthropology (e.g. Hastrup, 2018; Strathern, 2007), psychology (e.g. Good; Still, 1992) or other disciplinary traditions, taking interdisciplinarity - as either abstract concept or empirical work for object of study (see also Barry et al., 2008). What we intend to do in this article is something different: combining an empirical ethnographic approach with an effort to conceptually speculate based on social theory, instead of "anthropologizing" or "sociologizing" (in a reductive sense) the problems with interdisciplinary activity, we propose here a conceptual experiment. The intention is to produce new fields of visibility, concerning the elements and relations that structure disciplinary activity and interdisciplinary challenges. We are interested in exploring whether debates that deal with the relationship between the ethnographer and the other agents in the research may serve as a conceptual basis that helps us understand the relation among disciplines. What can the discussion of the philosophical problems

\footnotetext{
${ }^{1}$ Negotiating Environmental Knowledges was the title of a seminar organized by Sophie Haines at Oxford University on 12-13 December 2018, in which an earlier version of this article was presented.
} 
that characterize relationships between anthropologists and interlocutors say about relationships between anthropologists and climate scientists (ex. Edwards, 2010; Fine, 2007; Pennesi, 2013; Taddei, 2012), for instance? In following this path, we explore a dimension of the potential of the ethnographic enterprise to which Marilyn Strathern called attention, when she said that what "was always evident in anthropology's fieldwork mode, learning about social relations by acting out relationships with people, has recently become applicable to its position vis-à-vis other disciplines" (2006, p. 78). And yet, the goal of this paper is not to present an ethnographic analysis of scientific work, but rather to explore situations where borders make themselves most strongly felt, in the peculiar situation where the main goal is exactly to overcome them. It is the definition of such borderlines as the locus of this analysis that allows us to ask the reader to forgive the absence of a robust, sociological description of the worlds of both climatologists and social scientists.

In a second moment in the speculative maneuvering of the argument, we will draw conceptual inspiration from the field of indigenous ethnology. Especially generative for the argument of this paper are the ways in which conflict is ethnographically depicted, and enemies/others ethnologically constructed, in the worlds of Amazonian peoples. The intention here is to understand to what extent a discipline, in the context of Western academia, occupies positions that may be structurally equivalent to indigenous groups in relationship with others, and what that may suggest regarding how we understand tensions that may arise when (more or less) distinct academic disciplines engage with each other.

The research from which these reflections sprung has been in course for over a decade ${ }^{2}$, and focuses on the communication between those who produce seasonal climate forecasts and the "users" of these forecasts. In such endeavors, climatologists often characterize themselves as being at one end of a communicative chain, with "users" at the opposite end; a

\footnotetext{
${ }^{2}$ The authors would like to acknowledge funding that made the research efforts and seminar discussions possible: Inter-American Institute for Global Change Research (IAI) projects CRN3035 and CRN3106; São Paulo Research Foundation (FAPESP)/Belmont Forum, research project 2015/50687-8; the Oxford Martin Programme on Resource Stewardship; and UK Economic and Social Research Council grant ES/ N016084/1.
} 
position that reflects what science-policy scholars have called a "linear" or "dragnet" model of a unilinear flow from objective science to decisionmakers (McNie, 2013; Robinson, 1982). In this article, we are interested in understanding the expectations of climatologists and meteorologists engaged in these communicative processes, and what they mean when they use the word "interdisciplinarity". More recently, under the induction of the World Meteorological Organization (WMO), the concepts of "climate services" - in which the stated goal is to take into consideration, in unprecedented ways, the needs of the users - and "co-production of knowledge" have become prevalent, giving meteorology and climate science in general the hope that these concepts could be a safe guide to interdisciplinarity. ${ }^{3}$ And yet, this development has not changed - indeed, has arguably reinforced (e.g. Addor et al., 2015) - the fact that in the discourse of many meteorologists and other scientists (and funders), interdisciplinarity appears as a new EI Dorado, that is, a place that no one finds, but that everyone is sure that, if found, would bring plenitude and happiness to all involved.

There are evident platonic dimensions in the ways interdisciplinarity is placed in such a desired picture of the future. ${ }^{4}$ This paper advocates that interdisciplinarity should be approached instead through a relational/

\footnotetext{
${ }^{3}$ For a critical overview of some of these concepts and applications, see Goldman et al. (2018).

${ }^{4}$ Some of the implicit platonic qualities of much promotion of interdisciplinarity are very close to Christian theology. Examples are: the idea that there is an inherent "goodness" in interdisciplinarity, and therefore interdisciplinary advocates see themselves as morally "good," perhaps due to how they understand the activity as demanding high doses of tolerance, in the Christian understanding of the term (a more anti-Platonic approach, such as the one advocated by Isabelle Stengers (2011, p. 371) sees tolerance as a curse); and the common (self-)perception of the (social) scientist making the effort of doing interdisciplinarity in environmental research as a hero who is working to save the planet and those vulnerable to environmental change. There are three major problems with this picture: one is the tendency to flatten and essentialize the complex field of relations in which beings (material or ideological) relate to each other, reproducing a view of the sociological field as mechanistic and linear. Second, scientific activity is seen as the benign action of knowledgeable humans (virile hyper-agents) over disempowered groups of humans and non-humans (see the cover of the journal Nature, edition of 16 September 2015, for an unusually explicit example). The tendency for science to attribute to itself too much self-importance is permanently confronted by the empirical reality of how difficult it is to put science to productive use outside of the walls of the university (a large amount of science being just ignored), and also by feminist (Duran, 2018) and postcolonial critiques (Harding, 2015; Willey, 2016). And third, the amount of expectation and emotional investment by researchers, especially in earlier stages of their careers, on such unrealistic representation of matters, very easily leads to decrease in mental health (Green, 2017). In such panorama, individuals, matters, and the social sciences are essentialized in unproductive ways.
} 
constructivist framework, in which agents relate to each other ecologically, in the deep philosophical sense of the term (see Serres, 2007). In addition, the productive dimension of conflict, as employed in the argument of this paper, works in contraposition to such Platonism, assuming a rather more Nietzschean outlook.

With that said, it is important to state explicitly what this article is not trying to $\mathrm{do}^{5}$. It is a conceptual experiment with a clear pragmatic goal; it is not an attempt to present ethnographic theory as a universal antidote to the crisis of grand theoretical paradigms. Amerindian perspectivism has indeed been raised to the condition of a powerful critical theory, with effects that spill far beyond the social sciences. Our goal is far more humble - we do not try to address all the complex subtleties of Amerindian perspectivism, and still less of Amerindian thought in its ethnological diversity and complexity ${ }^{6}$. What we present here makes use of no more than a simplified version of the referred theory (abridged for our purposes), in a way that instead of presenting "just one more conceptual experiment with Amerindian thought," we feel it would be more appropriate to say that this is an experiment with the theory of perspectivism, nothing more.

\section{Tales of instructive equivocation}

We begin with two ethnographic tales. One of us (hereafter referred to as the social scientist) has conducted ethnographic research in the Brazilian Northeast region, both inside the local meteorological agency and with small farmers who were supposedly the most important recipients of the scientific information produced by the meteorological agency (due to the correlation between small family based agriculture in the semiarid region of Brazil and poverty; income tends to be strongly connected to the occurrence of rains for this social group). In the early stages of the ethnography, the social scientist dedicated some time to studying how ideas about nature, drought, water, and rain, existed in local narratives. After a number of interviews and a couple of months of research, the social scientist wrote a report where he

\footnotetext{
${ }^{5}$ We are grateful for the comments of two anonymous reviewers on this matter.

${ }^{6}$ Amerindian thought, as stated by some authors, greatly exceeds the theory of perspectivism in complexity and variation (see, for instance, Ramos, 2012; Turner, 2009).
} 
presented and discussed the data, referring, among other things, to what local authors call the "cultural water complex" (Taddei, 2004) - describing how water occupies a special place in the cultural schemes and constructs of people who live in arid and semiarid places. In that report the social scientist discussed how water has the power of agglutinating meaning, and ordering, in specific ways, emotional and perceptual patterns. That text was written as an initial exercise in the ethnographic work; at the same time, the social scientist had the feeling that he had to justify his presence inside of the meteorological agency, and so he decided to give a copy of the report to the manager of the institution's department of meteorology. The social scientist felt that his presence among them generated some degree of discomfort - not unusual in ethnographic research - and for that reason he imagined that if he showed them something real, like an academic report, they would be reassured. He also wanted to gauge their reactions to the kind of analysis he would be working with - one that is not centered on "nature," as is the case for their work, but more on "cultural" issues. Their response would certainly be an interesting piece of ethnographic data.

The manager took the report, read it, and came to talk to the social scientist the next day. It was all very well what the social scientist had written in the report, the meteorologist said; and yet, it was difficult for him to understand how it could be of any interest, from a scientific point of view. In his understanding, what the report described happened everywhere, with regional specificities and yet with an amazing degree of regularity: the Eskimo had esthetical appreciation and emotional bond to snow, the Swiss to the mountains, the forest dwellers to the forest, and so on. He could not see what relevance could exist in this type of investigation: what was being presented as worthy of academic interest was nothing more than common sense ${ }^{7}$.

\footnotetext{
${ }^{7}$ It is worth noting that this description does not correspond to the "prototypical" sequence of engagement between meteorologists and social scientists that was identified at the Oxford seminar (see footnote number 1) to be a common pattern: first the social scientist feels ignored (no interaction); then she becomes instrumental, usually via requests to help educate the public (form of interaction imposed by others); and finally the social scientist gains some degree of control over the interaction, and the relation reaches the phase of misunderstanding and conflict.
} 
Many years later, a similar ethnographic encounter took place, in a different setting. The social scientist was participating in the annual meeting of a multi-national, multi-disciplinary project focused on the concept of climate services, at the University of Buenos Aires. In his presentation, the social scientist explained to the other participants (many of whom were meteorologists), how the perception of utility exists among users of meteorological information, according to his ethnographic research. Part of the explanation centered on the fact that, if one has a large number of distinct user groups, each with their own demographic, economic, political, and sociological profiles, the criteria for what is or is not useful become very heterogeneous and variable; exploding in fractal fashion. Because of this, a computational model that produces forecasts may be very "good", according to the endogenous perception of meteorologists, and yet this does not say anything about what is going to happen with the scientific information once it gets disseminated. And, very often, even a very "good" forecast will be considered useless, from the perspective of a number of collectivities. Since the forecast will establish relations with an enormous amount of distinct practices and needs, due to the diversity of the collectivities with which it will interact, in each situation the utility will be constructed in distinct ways - very often in creative ways that differ significantly from the ideas meteorologists have about how forecasts should be properly used (Taddei, 2013).

At that moment in the talk, a Brazilian meteorologist and university professor who was in the group reacted, irritated, and began to explain to the social scientist that the utility of a forecast is related to the "skill" of the models used in its production; and the skill is measured based on how good the model is for predicting the climate of the past (so one can compare these predictions with the record of the real climatic events). This is what determines the utility of the models, and therefore of the forecasts produced by them, she said. A heated debate followed, in which the social scientist sustained that utility cannot be something endogenous to the model, but it is rather something necessarily relational, and therefore exogenous. The meteorologist maintained her defense that the utility of a forecast is 
constructed by meteorologists, through their continuous improvement of the mathematical and physical models used in their elaboration.

We will return to these encounters later in the development of the argument. But first, a methodological note. For most scholars from the natural and physical sciences, the most intuitive, and yet rational approach to studying how non-scientists or other scientists react to the products of the their research is through the study of success stories, trying to extract from them the "structural elements" of success that can be transferred and applied in different contexts. This approach is commonly called research on "best practices" (for an example on climate services, see Adams et al., 2015). ${ }^{8}$ Our approach here is almost the complementary opposite: our contribution to the debate draws inspiration from situations of tension in interdisciplinary work, grounded in ethnographic experiences in which anthropologists' relations with meteorologists did not function "well", at least not according to expectations of smooth integration and mutual alignment. Anchoring this approach is the idea that, without the awareness of most involved individuals, a large part of the existing research on interdisciplinary work, and particularly those studies grounded in the best practices framework, is vulnerable to what psychologists call confirmation bias - the tendency to put more attention on things that confirm our expectations about the world and less on those that don't; and that this affects negatively the perception of most people of the theoretical relevance of failure (see CRED, 2009). Theoretical approaches like those found in the ethnomethodology of Harold Garfinkel (1996) or in Actor-Network Theory suggest that friction and controversies give privileged access to the practices of composition and reproduction of social reality (Latour, 2008); Barry et al. (2008) suggest that agonistic-antagonistic modes of interdisciplinarity are more strongly associated than synthesis/subservience modes with epistemological and ontological transformations; and Anna Tsing's ethnographic approach to globalization (2005) foregrounds the creative powers of friction among worldviews.

\footnotetext{
${ }^{8}$ There is also a literature on "barriers" to success, though much of this work is framed around overcoming them in order to achieve integration.
} 


\section{Variables, axioms, doxa, and the unavoidable positionality of knowledge}

What we will do next, as a proposition for a novel approach to problems related to interdisciplinary relations, is also a conceptual experiment. In the first movement, we will use concepts and language that come from the philosophy of sciences in an attempt to make evident what we believe to be a fundamental dimension of interdisciplinary antagonisms. In the second movement, we will bring in elements from ethnological theories about conflict, and we will project them over the scheme constructed in the first part and see whether something relevant is then revealed.

Let us adopt for a moment a conceptual framework that organizes the work of the sciences according to three ontological dimensions. One refers to variables, the second to axioms, and the third to what sociologists call doxa (Bourdieu, 1990). Variables are the focus of attention of the scientific activity; it is what varies, supposedly outside of the control of the researcher, and therefore teaches her something about causal relations in reality. Axioms are the presuppositions, logical, epistemological, or ontological, that makes scientific work with variables function appropriately. All sciences have their axioms; they are part of the logic structure of the scientific fields, and yet they are not variables, and therefore they are not (normally) subject to criticism and test. Their function is to ground the work of testing variables. Doxa, in its turn, is the phenomenal world that exists behind all forms of social action - including scientific work -, and that is taken for granted. It is not articulated as part of the problem, nor as part of the available tools for addressing the problem. Doxa is then the dimension of reality - physical or otherwise - that is not articulated; it is so "obvious" that it does not get to be developed in discursive terms. Axioms are different from doxa because, once accepted tacitly, they exist in structured, coordinated ways: scientists know very well the axioms that take part in shaping their reasoning, and use them as a framing device in order to be able to work with variables.

We posit that what happened in the described conflicts between the social scientist and his meteorological friends is as follows: what for the social scientist is one thing in this tryptic scheme, is a different thing for 
the meteorologist. When the social scientist presented the manager of the meteorological agency with his work on the cultural water complex of the semiarid region, he elected as his variable the diverse ways the collectivities of Brazil's Northeast region configure coherent systems of meanings and symbols. The manager's reaction was to tell the social scientist, albeit with different words, that what the latter decided to treat as variable was actually part of the doxa, and that is why it seemed to be irrelevant in the perception of the former - precisely for being part of the doxa, something cannot be a variable. Without noticing it, the meteorologist was effectively disarticulating the social scientist's work. If the social scientist followed the line of research that he proposed himself to do (as indeed he did), the relationship between disciplines, and therefore researchers, would necessarily become marked by the existence of tension. The very fact that the social scientist was claiming that there is a variable linked to the cultural dimension in the set of environmentally relevant problems has the potential for disorganizing the world as it is organized inside of meteorology. The meteorologists have their variables and axioms, and - though in nonarticulated forms - their doxa. The focus of their intellectual investment, which is also the focus of their emotional investment, exists over the pair variables-axioms, upon which they construct the conceptual architecture of the research - and upon which are also constructed institutional networks, bureaucracies, schemes for distribution of research funds, hierarchies, complex distinction mechanisms, and so forth. When a social scientist arrives and says that it is important to extract something from the doxa and bring it to the set of variables, this disorganizes the cognitive and affective work of the meteorologist, to the point that an emotional reaction should be expected. That is, we argue, exactly what happened in the second vignette. It obviously functions similarly the other way around: for example, when someone from sociobiology tells a constructivist social scientist that patterns of cultural behavior can be explained by things like genetics, this disorganizes the world of the latter, makes her nervous, and puts her in defensive mode. Methodological distinctions can reflect fundamentally different principles/doctrines (for example utilitarian versus rights-based 
ethics), the rationality and legitimacy of which may require the exclusion of insights from opposing paradigms (Rayner; Malone, 1998). ${ }^{9}$

What we are trying to say here is that there are things that are more complex, in interdisciplinary research and work, than the issue of people having or not the inclination to sit and talk to members of other disciplinary groups. The simple existence of a field of disciplinary work can disorganize another field of work. Perhaps that is why the universities are built with such thick walls, symbolically and bureaucratically speaking, and also with doors that are often carefully locked.

\section{The importance of the enemy: interdisciplinarity without romanticism}

So far, the picture presented in this text is not a particularly happy one. The awareness that, in most cases, conflict is a logical outcome of putting disciplines in contact probably depresses most well-intentioned academics. This happens, however, only if they have a certain understanding of what a conflict is, and also of what is to be done with respect to the other parties in the conflict situation. In other terms, the ontological framing of conflicts makes a difference. A framing grounded in the ontological regime that Descola (2013) called naturalistic hypostasizes material (and social) realities and at the same time makes them the ultimate reference point for the production of Truth with capital T, through the production of Nature with capital $\mathrm{N}$. The transcendental value attached to such capitalized truth/ nature, and the assumption that all beings are axiomatically inhabitants of the same (material) reality, turns the quest for truth into a political matter, making epistemological alliances a necessary requirement for collaboration. In simple terms, some people are understood to be wrong, in need of being convinced otherwise, and if they resist, they become epistemologically - and

\footnotetext{
${ }^{9}$ Rayner and Malone (1998, p. 36) propose that the most significant "intellectual rupture" is located not between the physical and social sciences, as often assumed, but rather within the social sciences - between the descriptive, epistemologically realist approaches more easily integrated with physical sciences on one hand, and interpretive approaches aligned with the humanities, on the other. Strathern (2006) highlights a distinction between ethos and practices of research versus managerial modes of knowledge generation.
} 
therefore politically - dangerous. They are the epistemological enemies, in a social world that has a millenary tradition of killing, in small and large scale, due to epistemological discord (see, for instance, the role of interpretation in the religious wars of European Christianity).

It is against the ontological background of the milieu in which Western sciences developed that we propose our conceptual experiment. It is an attempt to understand how Amazonian indigenous ethnology - to use Descola's parlance, how an ontological regime of animism - presents us with ideas to make sense of the question of alliances among enemies. The goal is, after having presented a rather gloomy perspective on how disciplinary groups related to each other, to see whether ethnology may show an interesting alternative for cooperation among dissimilar parties.

One of the pervasive elements in the indigenous ethnology we draw on here, and one that makes it compelling, in our perception, as a conceptual strategy for addressing situations of conflict in interdisciplinary work, is the lack of an illusion among researchers who work with this type of ethnographic knowledge that conflicts will be solved. One prerequisite for taking Amerindian societies seriously is to understand and accept that interethnic conflicts will not, and cannot, be "resolved", because they are part of how indigenous worlds constitute themselves (Viveiros de Castro, 2002). Of course, what exactly ethnic conflict consist of, in the context of the contemporary multidimensional transformation of the lives of most Amazonian peoples, is an empirical question. And yet, there is overwhelming ethnological evidence that the majority of indigenous populations in the Americas, and also in other parts of the world, such as Siberia (Vitebsky; Alekseyev, 2015), and Papua New Guinea (Strathern, 1988), understand that individuals and collectivities constitute themselves in direct relation to antagonism, to whatever offers resistance to the development and exercise of agency, be it in the formation of personality (such as in a myriad of rites of passage, for instance), or of political collectivities. In many cases, this assumes the form of a transcendental enemy (Viveiros de Castro, 2002), one against which energies are channeled, and the very process of channeling such energies is constitutive of most of the social and cultural structures required for social life. Eventually, in the material and spiritual conditions of 
ethnographic experience, this transcendental enemy may become corporified through the mediation of the existence of an antagonistic ethnic group, and this is the situation in which physical interethnic conflict may erupt.

The idea that antagonism is productive in the materialization of concepts and realities is not totally foreign to Western thought. For example, one definition of "nature" posits that it has been historically constructed as exactly everything that offers resistance to human agency (Pearson, 2015); the more effective the resistance, the more "natural" the phenomena in question, from simple unexpected and uncomprehended transformation in one's body to events that are so sensorially and cognitively overwhelming that they produce what Kant ([1961] 2003) called the sublime.

The point we want to make here is that there is a form of equivocation that crosses through interdisciplinary thinking: we most of the time do not perceive, and the rest of the time do not admit, that there is some degree of structural equivalence between what concerns the relations among academic disciplines, and what interethnic conflict is for the Amazonian peoples. The interdisciplinary conflicts are part and parcel of the processes through which the world of academic disciplines is composed and reproduced in time. Not everything is conflict in the everyday life of most scientific research; and yet, what cognitive scientists (and before them, structural anthropologists) describe as the human tendency for thinking in binary terms may be just the cognitive face of using antagonism for productive conceptual work. Conflict is, in such context, not a "failure". Most of us academics live in a state of denial about this simple fact. In not facing it seriously, we remain searching for El Dorado.

Our proposition in the direction sketched is, then, to represent doxa, axioms, variables, and conflicts in a genealogical diagram (see figure below) - a tool borrowed from indigenous ethnology. Distinct but proximal disciplines can be understood as being capable of establishing relations of consanguinity (in kinship terms), and that can happen for the sharing doxa, when ontological distances are big, or doxa and axioms, for smaller ontological rifts, even when variables are not shared. We may think about disciplines like genetics and clinical oncology, for instance. It is not hard to see that there are ontological and epistemological commonalities to the work of 
both - the naturalistic, materialistic approach; the centrality of the inductive reasoning; the importance of certain entities, like cells and molecules, to cite a few examples. As a result, even if both disciplines work with different objects and variables, we can think about the sharing of axiomatic elements as structural equivalent to the sharing of "substances" that characterizes consanguinity. We may think about two other cognate disciplines, such as quantum mechanics and electric engineering. Here the same thing happens: there are shared axiomatic elements. In epistemological terms, also the preference for a naturalistic, materialistic, and inductivist approach to the phenomena they work with; in ontological terms, the centrality of entities such as electrons and electromagnetic waves, for instance. Once again, something equivalent to consanguinity. ${ }^{10}$

\section{Figure - Genealogical diagram: doxa, axioms, variables and conflict}

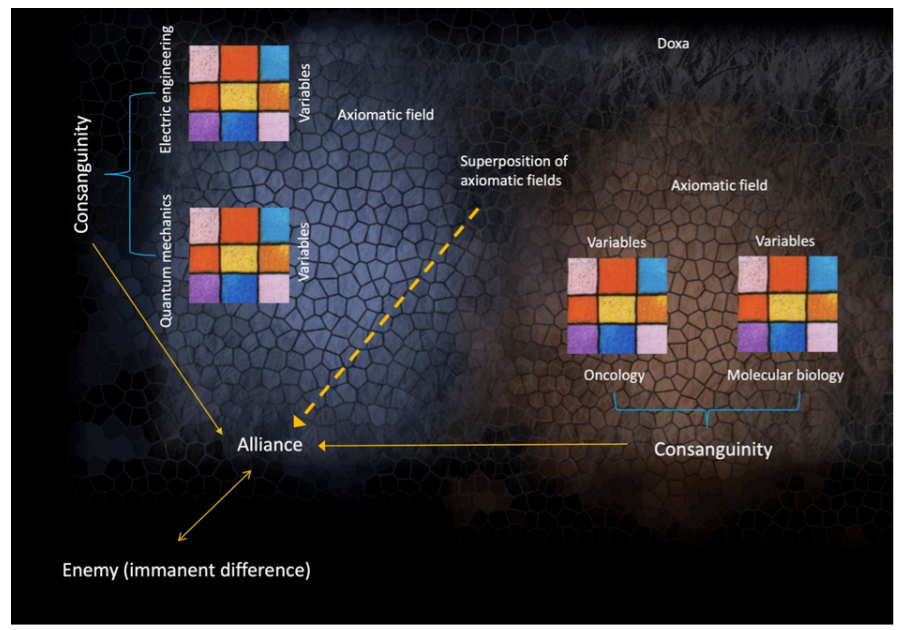

Source: image composed by the authors, with graphic elements taken from Pics4Learning. $\mathrm{com}^{11}$

\footnotetext{
${ }^{10}$ The foregrounding of consanguinity/shared substance is only one approach to reckoning kinship (see for example Weston, 1991).

${ }^{11}$ Images used: Oaks, Linda. fabric107.jpg. 2007. Pics4Learning. 5 Aug 2019; O'Neill, Destin. destinoneill7.jpg. January 2014. Pics4Learning. 5 Aug 2019; Swan, Chelsea. swan21234.jpg. 05/30/05. Pics4Learning. 5 Aug 2019.
} 
There are situations in which different consanguineous groups may establish alliances (even in the presence of endemic conflictive relations among them); this can happen when there is a powerful common enemy who could easily overcome any of the groups individually. So any group needs the other in order to engage in the conflict. To make use of the disciplines mentioned above, we can think about a situation in which a community wants to start a legal action against a telecommunications company for the installation of a huge antenna in a given place that, it is supposed, increased the number of cases of cancer in the community. There we have a problem of molecules, cells, electrons, and electromagnetic waves. It is possible to search for areas of superposition inside of the axiomatic fields of each discipline - an area of superposition that allows for the construction of common action strategies. This happens not so much in what is concerned with the ontological dimensions - in the short term, no one expects that medicine will be able to talk about electromagnetic waves with the same authority that the physicists have (that is, in the way that interests physicists); nor that physicists would hold the same authority to talk about cells, in their turn. Yet, in methodological and epistemological grounds this alignment is not very difficult -- the principles of rationality, materiality, and inductivity are widely shared among these collectivities. There resides the possibility of alliance.

What the indigenous ethnology we refer to here suggests, in this model, is that there are barriers to be overcome in the process of constructing alliances, even when the shared epistemological and cultural principles are in place. It is here that the enemy plays a crucial role: it gives the impetus for surpassing these barriers. Ailton Krenak, one of the most important indigenous leaders in Brazil, once said that:

We are all traditional enemies. Now, you still didn't understand that, in the psychology of the indigenous peoples, the traditional enemy is the one that you preserve, even more than the traditional friend. A traditional friend you can lose at any time, while the traditional enemy you keep. I preserve my traditional enemies until the last moment. You know that headdress that begins with a green feather here, and then there is a variation of tones, another blue feather and another green at the end? The traditional friend is this one, the traditional enemy is this one, you couldn't find two people so close to each 
other than the traditional friend and the traditional enemy (Krenak in Ricardo; Villas Boas, 2015, p. 56).

The enemy is to be cared for; in large parts of the indigenous lowlands of South America, one constructs her identity and the conditions of her existence in the world from the relationship established with the enemies. Paradoxically, these can be relationships of trust and amicability (SantosGranero, 2007). In more structural terms, the enemy is the immanent, invisible difference (Viveiros de Castro, 2010). It is as if all the aforementioned scheme of consanguinity and alliances (among ethnic groups and academic disciplines) constituted itself in reaction to something; and this something, even if not well defined and explicit, is what justifies the existence of the whole scheme. Alterity seems to be required for the generation of the energy needed for the setting up of such alliances and networks.

This puts in evidence the importance of the enemy, and therefore of the conflict, in its constitutive dimension. At this point, it should be clear that the meaning associated with the concept of enemy in Amerindian philosophies has little connection to what the same word stands for in most Western circumstances. Typically, Amazonian peoples do not engage in genocidal war. The idea of total destruction of the enemy seems to be absent from Amazonian philosophies.

Returning to the question of the interdisciplinary relations, there is an important historical matter that needs to be addressed, and it refers to the fact that natural sciences and social sciences - or, as per Rayner and Malone (1998), descriptive and interpretive approaches - have recurrently positioned themselves as traditional enemies - and this dates back at least to Kant. They have acted as such throughout the $20^{\text {th }}$ century, and the trouble entered the $21^{\text {st }}$ (think of the Sokal affair and its reiterations - see Klein, 2018). Walford (2012, p. 114) notes that such conflicts between constructivism and objectivism suggest that there is nonetheless a common understanding that knowledge and ideas can travel and be controlled, even if the ways in which ideas have travelled has involved much misunderstanding and frustration. To "fix" the situation now is far from being a simple task; the weight of the historical record of conflict is heavy. So, based on the argument presented so far, instead of attempting to make these scientific 
fields stop treating each other as enemies, it seems more realistic and more productive to understand how alliances can be made. In the specific field of the relations of meteorologists and social scientists, there is clearly a new enemy on the stage, and the reason why there are so many anthropologists and sociologists working inside meteorological institutions, and in large research projects led by climate scientists, is that it is not just a new enemy, but one with so much power that it enables axiomatic agreements to be constructed with inedited amount of intensity. This new enemy is climate change.

The framework we propose above adds to recent works on interdisciplinarity in climate change research and related topics, and, we suggest, offers a generative analytical lens through which to address interdisciplinarity's promises and problems. Sarah Vaughn (2017, p. 262), for example, uses the concept of 'inverse performativity' to argue that the growing material and intellectual challenges of climate change are compelling experts from different disciplines, fields and sectors to work together and to reshape their paradigms in a "new ecology of expertise". New relationships and constellations of relationships of this kind can be controversial, spanning a range of ecological interactions including symbiosis, predation and parasitism (Serres, 2007). Care, preservation, and hosting all have roles in the construction of alliances among enemies - those with whom substances-axioms are not readily shared. Difference, proximity and identity may be established and practiced on day-to-day basis within and among groups of scientists (Walford, 2012); friendships can be established between individuals who are members of enemy groups (Santos-Granero, 2007). A relational approach to interdisciplinarity draws attention to systems of responsibility (Whyte, 2013) as well as connections of substance, and is open to the potential productivity of both alliance and difference.

\section{Concluding remarks}

Finally, if we compare the options that we have in relation to all that was exposed here, we see, on one side, the expectation of disciplinary metamorphosis - the hope that the fields of the social sciences, of the 
physical sciences, and of all other existing sciences, transform into something different from what they are. This is what generally underlies the immense majority of analyses of interdisciplinary problems and relations. There is here a detachment between what we are addressing and indigenous ethnology: in spite of the importance of the concept of metamorphosis in indigenous cosmologies (that includes the danger of the metamorphosis of an individual into someone of the species of enemy, especially in predator-prey relations), in the Western world of disciplinary academia there are at least two elements that work against it: first, the already mentioned institutional and bureaucratic academic organization that was historically constituted through the imposition of barriers and limitations, so as to minimize the risk of "Contamination" from other disciplines (Bourdieu, 2000; Gieryn, 1983); and second, the tendency among Western collectivities to strengthen identity definition and stabilization, in conservative ways, in situations of uncertainty and risk (Douglas, 1992). On that, Marilyn Strathern (2007, p. 131) refers to the "convenient" fiction of distinct disciplines in terms of defining accountability and authentication. Given this situation, the expectation that academic disciplines will change endogenously, out of an inner will to change, exists in contradiction to these factors, and therefore appears as a formidable challenge. ${ }^{12}$

Another possibility is that the aptitude for transformation should not be expected from disciplines, but from individuals with special metamorphic powers. The structural equivalent to those individuals in the Amazonian world are the shamans - strange, special individuals who are capable of transforming into animals and then returning, and whose powers are, though dangerous, fundamental to the existence of the indigenous worlds. In the realm of academic disciplines, the equivalent would be strategic intermediaries, people socialized in distinct worlds and in unorthodox ways, and for this very reason, capable of navigating distinct epistemological and ontological universes, in the physical and the social sciences. Our ethnographic experience in border situations

\footnotetext{
${ }^{12}$ With reference to anthropology's disciplinary identity and potential for transformation, Chua and Mathur (2018) have recently appealed for a rethinking of the anthropological 'we', and a move to reach out into new spaces of knowledge production and experience, aligned with a decolonizing agenda.
} 
where the physical sciences touch the social sciences has shown that these beings capable of metamorphosis are frequently in the so-called "applied fields", be they physical or social, and not in the high hierarchical levels in their institutions. In relation to climate issues, these individuals tend to be agronomists, cartographers, hydrologists, union leaders, activists, health agents, nurses, rural schoolteachers, technicians at municipal governments and - indeed - shamans (Arregui 2018; Kopenawa; Albert 2013). The work of professionals with such characteristics tends to be based on the translation of meanings, creative construction of pragmatic solutions and management of expectations (Haines, 2019), where the criteria for success are based on the satisfaction of the involved collectivities, and the adopted strategies seem often to lack conceptual or epistemological coherence. In this, it what resembles shamanism: the possibility of constructing improbable bridges across incoherent worlds, resulting in different people acting together, in satisfactory ways, without thinking alike. Eduardo Viveiros de Castro called it controlled equivocation (Viveiros de Castro, 2004); Mauro Almeida called it pragmatic agreement (Almeida, 2017). Arregui (2018), discussing how a climatologist and a shaman have deployed mimicry and diplomacy in public dialogue, argues they are able to forge new forms of ecopolitical connectivity across different perspectives, in the face of a shared struggle against climate-related crises (see also Kopenawa; Albert 2013). This work can be both frustrating and revelatory. What matters is the recognition that systematic misunderstanding is a fundamental building block in the composition of reality; something that can be informative and transformative. Much of the debate on interdisciplinarity's virtues and sins is an abiding lament about people's inability to produce a perfect attunement of minds and concepts. As we hope to have demonstrated throughout this text, this is definitely not necessary. 
Renzo Romano Taddei holds a PhD in Anthropology. He is Professor at the Department of Marine Sciences and at the Graduate Program in Social Sciences in the Federal University of São Paulo.

Đ renzo.taddei@unifesp.br.

Sophie Haines holds a PhD in Anthropology. She is a Lecturer in Anthropology of Development at the University of Edinburgh, and a Research Affiliate of the School of Anthropology and Museum Ethnography, University of Oxford.

ఏsophie.haines@ed.ac.uk.

\section{References}

1. ADAMS, Peter; EITLAND, Erika; HEWITSON, Bruce; VAUGHAN, Catherine; WILBY, Robert; ZEBIAK, Stephen. Toward an ethical framework for climate services: a white paper of the Climate Services Partnership Working Group on climate services ethics. Climate Services Partnership, 2015.

2. ADDOR, Nans; EWEN, Tracy; JOHNSON, Leigh; ÇÖLTEKIN, Arzu; DERUNGS, Curdin; MUCCIONE, Veruska. From products to processes: academic events to foster interdisciplinary and iterative dialogue in a changing climate. Earth's Future, v. 3, n. 8, p. 289-297, 2015. doi: 10.1002/2015EF000303

3. ALMEIDA, Mauro. Local Struggles with entropy: Caipora and other demons. In: BRIGHTMAN, Marc; LEWIS, Jerome (Eds.) The anthropology of sustainability. New York: Palgrave, 2017.

4. ARREGUI, Aníbal G. Embodying equivocations: ecopolitical mimicries of climate science and shamanism. Anthropological Theory, 2 February 2018. doi: 10.1177/1463499617753335.

5. BARRY, Andrew; BORN, Georgina; WESZKALNYS, Gisa. Logics of interdisciplinarity. Economy \& Society v. 37, n. 1, p. 20-49, 2008. doi: 10.1080/03085140701760841.

6. BOURDIEU, Pierre. The logic of practice. Stanford: Stanford University Press, 1990.

7. BOURDIEU, Pierre. Intelectuales, política y poder. Buenos Aires: Eudeba, 2000.

8. CRED - Center for Research on Environmental Decisions. The psychology of climate change communication. New York: CRED, Columbia University, 2009.

9. CHUA, Liana; MATHUR, Nayanika. Introduction: who are "we"? In: CHUA, Liana; MATHUR, Nayanika (Eds.). Who are "we"? Reimagining alterity and affinity in anthropology. New York: Berghahn, 2018, p. 1-34.

10. DESCOLA, Philippe. Beyond nature and culture. Chicago: University of Chicago Press, 2013. 
11. DOUGLAS, Mary. Risk and blame: essays in cultural theory. London: Routledge, 1992.

12. DURAN, Jane. Philosophies of science: feminist theories. London: Routledge, 2018.

13. EDWARDS, Paul N. A vast machine: computer models, climate data, and the politics of global warming. Cambridge, MA, USA: The MIT Press, 2010.

14. FINE, Gary A. Authors of the storm: meteorologists and the culture of prediction. Chicago, IL: University of Chicago Press, 2007.

15. GARFINKEL, Harold. Ethnomethodology's program. Social Psychology Quarterly, v. 59, n. 1, p. 5-21, 1996. doi: 10.2307/2787116

16. GIERYN, Thomas F. Boundary-work and the demarcation of science from non-science: strains and interests in professional ideologies of scientists. American Sociological Review, v. 48, n. 6, p. 781-795, 1983. doi: 10.2307/2095325.

17. GOLDMAN, Mara. J.; TURNER, Matthew J., DALY, Meaghan. A critical political ecology of human dimensions of climate change: epistemology, ontology, and ethics. Wiley Interdisciplinary Reviews: Climate Change, v. 9, n. 4, p. e526, 2018. doi: 10.1002/wcc.526

18. GOOD, James M.; STILL, Arthur W. The idea of an interdisciplinary social psychology: an historical and rhetorical analysis. Canadian Psychology/ Psychologie canadienne, v. 33, n. 3, p. 563-568, 1992. doi: 10.1037/h0078731

19. GREEN, Emily. The existential dread of climate change - how despair about our changing climate may get in the way of fixing it. Psychology Today, Oct 13, 2017. Available at https:/www.psychologytoday.com/us/blog/there-is-alwaysanother-part/201710/the-existential-dread-climate-change

20. HAINES, Sophie. Managing expectations: articulating expertise in climate services for agriculture in Belize. Climatic Change, 2019. doi: 10.1007/s10584018-2357-1

21. HARDING, Sandra. 32 postcolonial and feminist philosophies of science and technology. In: NAYAR, Pramod K. (Ed.) Postcolonial studies: an anthology, 2015. p. 533-552.

22. HASTRUP, Kirsten. Collaborative moments. Expanding the anthropological field through cross-disciplinary practice. Ethnos, v. 83, n. 2, p. 316-334, 2018. doi: 10.1080/00141844.2016.1270343

23. HOLMWOOD, John. Sociology's misfortune: disciplines, interdisciplinarity and the impact of audit culture. British Journal of Sociology, v. 1, n. 4, p. 639658, 2010. doi: 10.1111/j.1468-4446.2010.01332.x

24. KANT, Immanuel. Observations on the feeling of the beautiful and sublime. Trans. John T. Goldthwait. University of California Press, [1961] 2003.

25. KLEIN, Steven. The new science wars. The Chronicle of Higher Education, December 16, 2018. Available at https://www.chronicle.com/article/The-NewScience-Wars/245333. 
26. KOPENAWA, Davi; ALBERT, Bruce. The falling sky: words of a yanomami shaman. Cambridge: Harvard University Press, 2013.

27. LATOUR, Bruno. Reensamblar lo social. Una introducción a la teoría del actor-red. Buenos Aires: Ediciones Manantial, 2008.

28. LIMA, Tânia S. O dois e seu múltiplo: reflexões sobre o perspectivismo em uma cosmologia tupi. Mana, Rio de Janeiro, v. 2, n. 2, p. 21-47, 1996. doi: 10.1590/S0104-93131996000200002

29. MCNIE, Elizabeth. Delivering climate services: organizational strategies and approaches for producing useful climate-science information. Weather, Climate and Society v. 5, p. 14-26, 2013. doi: 10.1175/WCAS-D-11-00034.1.

30. PEARSON, Chris. Beyond 'resistance': rethinking nonhuman agency for a 'more-than-human' world. European Review of History/ Revue européenne d'histoire, v. 22, n. 5, p. 709-725, 2015. doi: 10.1080/13507486.2015.1070122

31. PENNESI, Karen. Predictions as lies in Ceará, Brazil: the intersection of two cultural models. Anthropological Quarterly, v. 86, n. 3, p. 759-790, 2013. doi: 10.1353/anq.2013.0038

32. RAMOS, Alcida R. The politics of perspectivism. Annu. Rev. Anthropol. v. 41, p. 481-94, 2012. doi: 10.1146/annurev-anthro-092611-145950.

33. RAYNER, Steve; MALONE, Elizabeth L. Human choice and climate change. v. 4: What have we learned? Columbus: Battelle Press, 1998.

34. RICARDO, Beto; VILLAS BOAS, André. A Aliança dos Povos da Floresta [Interview with Ailton Krenak and Osmarino Amâncio]. In: COHN, Sergio (Org.) Ailton Krenak. Série Encontros. Rio de Janeiro: Azougue, 2015.

35. ROBINSON, John B. Apples and horned toads: on the framework-determined nature of the energy debate. Policy Sciences v. 15, n. 1, p. 23-45, 1982. doi: 10.1007/BF00143365

36. SANTOS-GRANERO, Fernando. Of fear and friendship: Amazonian sociality beyond kinship and affinity. Journal of the Royal Anthropological Institute v. 13, n. 1, p. 1-18, 2007. doi: 10.1111/j.1467-9655.2007.00410.x

37. SERRES, Michel. The Parasite. Minneapolis: The University of Minnesota Press, 2007.

38. STENGERS, Isabelle. The curse of tolerance. In: Cosmopolitics II. Minneapolis: The University of Minnesota Press, 2011. p. 303-311.

39. STRATHERN, Marilyn. The gender of the gift. Berkeley: University of California Press, 1988.

40. STRATHERN, Marilyn. Useful knowledge. Proceedings of the British Academy, v. 139, p. 73-109, 2006.

41. STRATHERN, Marilyn. Interdisciplinarity: some models from the human sciences. Interdisciplinary Science Reviews, v. 32, n. 2, p. 123-134, 2007. doi: 10.1179/030801807X163562 
42. SZOSTAK, Rick. The state of the field: interdisciplinary research. Interdisciplinary Studies, v. 31, p. 44-65, 2013. doi: 10.7939/R3QB9V49Q

43. TADDEI, Renzo. Notas sobre a vida social da previsão climática. Um estudo do caso do Ceará. In: LALL, Upmanu; SOUZA FILHO, Francisco de A. (Eds.). Gerenciamento integrado dos recursos hídricos com incorporação da previsão climática: da informação e previsão climática à redução das vulnerabilidades às secas no semi-árido Cearense. Palisades/Fortaleza: IRI e FUNCEME, 2004.

44. TADDEI, Renzo. The politics of uncertainty and the fate of forecasters. Ethics, Policy \& Environment, v. 15, n. 2, p. 252-267, 2012. doi: 10.1080/21550085.2012.685603

45. TADDEI, Renzo. Anthropologies of the future: on the social performativity of (climate) forecasts. In: KOPNINA, Helen; SHOREMAN-OUIMET, Eleanor (Eds.). Environmental anthropology, future directions. London: Routledge, 2013.

46. TSING, Anna L. Friction: an ethnography of global connection. Princeton: Princeton University Press, 2005.

47. TURNER, Terry S. The crisis of late structuralism. perspectivism and animism: rethinking culture, nature, spirit, and bodiliness. Tipití: Journal of the Society for the Anthropology of Lowland South America, v. 7, n. 1, p. 1, 2009.

48. VAUGHN, Sarah. Disappearing mangroves: the epistemic politics of climate adaptation in Guyana. Cultural Anthropology v. 32, n. 2, p. 242-268, 2017. doi: 10.14506/ca32.2.07.

49. VITEBSKY, Piers; ALEKSEYEV, Anatoly. Siberia. Annual Review of Anthropology, v. 44, p. 439-455, 2015. doi: 10.1146/annurev-anthro-092412-155546

50. VIVEIROS DE CASTRO, Eduardo. Perspectivismo e multinaturalismo na América indígena. In: A inconstância da alma selvagem. São Paulo: Cosac Naify, 2002, p. 345-399.

51. VIVEIROS DE CASTRO, Eduardo. Perspectival anthropology and the method of controlled equivocation. Tipití: Journal of the Society for the Anthropology of Lowland South America, v. 2, n. 1, p. 3-22, 2004.

52. VIVEIROS DE CASTRO, Eduardo. Metafísicas caníbales. Buenos Aires: Katz Editores, 2010.

53. WALFORD, Antonia. Data moves: taking Amazonian climate science seriously. Cambridge Anthropology v. 30, n. 2, p. 101-117, 2012. doi: 10.3167/ ca.2012.300207.

54. WALLACE, Richard. L.; CLARK, Susan G. Convergent evolution in the interest of integrative problem solving: connecting the policy sciences and interdisciplinary studies. Interdisciplinary Studies, v. 32, p. 134-169, 2014.

55. WESTON, Kath. Families we choose: lesbians, gays, kinship. New York: Columbia University Press, 1991. 
56. WHYTE, Kyle P. Justice forward: tribes, climate adaptation and responsibility. Climatic Change v. 120, n. 3, p. 517-30, 2013. doi: 10.1007/s10584-013-07432.

57. WILLEY, Angela. A world of materialisms: postcolonial feminist science studies and the new natural. Science, Technology, \& Human Values, v. 41, n. 6, p. 9911014, 2016. doi: 10.1177/0162243916658707. 